\begin{tabular}{|c|c|c|}
\hline Dinamika Journal, Vol. 1 No. 4, 2019 \\
ISSN ONLINE : 2686-2158
\end{tabular}

\title{
PEMBERDAYAAN KADER PENDETEKSI TUBERKULOSIS PARU MENUJU DESA LINGGASARI YANG SEHAT DAN PRODUKTIF
}

\author{
Dwi Sarwani Sri Rejeki ${ }^{1, *}$, Sri Nurlaela ${ }^{1)}$, Dian Anandari ${ }^{1)}$ \\ 1) Jurusan Kesehatan Masyarakat Fakultas Ilmu Ilmu Kesehatan, Universitas Jenderal \\ Soedirman, Purwokerto, Indonesia \\ *Corresponding author: dwisarwanisr@yahoo.com
}

Received 30 September 2019; Accepted 30 December 2019; Available online 31 December 2019

\begin{abstract}
Abstrak
Indonesia merupakan salah satu dari 5 negara dengan insiden tertinggi di dunia. Penemuan penderita TB paru secara aktif di masyarakat sangat penting untuk mencegah penularan lebih lanjut. Alternatif program pemberantasan TB paru adalah dengan Active Case Finding yaitu menjaring suspek TB paru dengan melibatkan peran serta masyarakat termasuk kader untuk meningkatkan angka cakupan (coverage) penemuan, pemeriksaan dan pengobatan TB paru. Kabupaten Banyumas termasuk kategori risiko sedang dalam kasus TB paru. Desa Linggasari Kecamatan Kembaran Kabupaten Banyumas merupakan salah satu dengan yang angka Case Detection Rate (CDR) atau angka penemuan kasus rendah. Karakteristik lain desa ini adalah merupakan desa salah satu desa dengan tingkat sosial ekonomi rendah. Kader yang ada di Linggasari mempunyai pengetahuan yang terbatas tentang TB paru, yang berdampak pada sedikitnya penemuan aktif penderita TB paru di Desa Linggasari. Untuk membantu mengatasi masalah ada beberapa upaya yang dilakukan pengkaderan, pendidikan/pelatihan dan pendampingan. Hasil kegiatan menunjukkan ada perubahan pengetahuan dan ketrampilan kader dalam penemuan penderita TB paru. Diharapkan dari kader ini dapat membantu proses penemuan, pengobatan dan pengawasan penderita TB paru sehingga menjadikan masyarakat sehat dan produktif.
\end{abstract}

Kata Kunci : Tuberkulosis Paru, kader, pemberdayaan

\begin{abstract}
Indonesia is one of the 5 countries with the highest incidence of tuberculosis in the world. The discovery of active pulmonary $T B$ patients in the community is very important to prevent further transmission. An alternative program to eradicate pulmonary $T B$ is Active Case Finding, which is to collect suspected pulmonary TB by involving community participation, including cadres, to increase the coverage of pulmonary TB discovery, examination and treatment. Banyumas Regency is included in the moderate risk category for pulmonary TB cases. Linggasari Village, Kembaran Subdistrict, Banyumas Regency is one with a low Case Detection Rate (CDR) rate. Another characteristic of this village is that it is a village with a low socioeconomic level. Cadres in Linggasari have limited knowledge about pulmonary TB, which results in the lack of active discovery of
\end{abstract}


pulmonary TB sufferers in Linggasari Village. To help overcome the problem, there are several efforts made by cadre, education / training and assistance. The results of the activity showed that there was a change in cadre knowledge and skills in the discovery of pulmonary TB sufferers. It is hoped that from this cadre can help the process of finding, treating and monitoring pulmonary TB patients so as to make the community healthy and productive.

Keywords: tuberculosis, cadres, empowerment

\section{PENDAhuluan}

Tuberkulosis paru (TB paru) adalah suatu penyakit menular yang disebabkan bakteri mycobacterium tuberculosis dan menyerang organ paru (Reyn, 2013). Secara global pada tahun 2016 terdapat 10,4 juta kasus insiden TB paru yang setara dengan 120 kasus per 100.000 penduduk. Lima negara dengan insiden kasus tertinggi yaitu India, Indonesia, China, Philipina, dan Pakistan (Kementerian Kesehatan RI, 2018). Penyakit tuberkulosis paru pada tahun 2014 menduduki peringkat kedua penyebab kematian tertinggi akibat penyakit infeksi setelah Human Immunodeficiency Virus (HIV), dimana pada tahun 2000-2013 diperkirakan 37 juta jiwa diselamatkan melalui diagnosis yang efektif dan tatalaksana yang baik. Jumlah kasus baru TB di Indonesia sebanyak 420.994 kasus pada tahun 2017(Kemenkes Republik Indonesia, 2019)

Strategi program penanggulangan TB yang digunakan di Indonesia adalah strategi DOTS (Directly Observed Treatment Shortcourse). Penemuan penderita TB paru dalam strategi ini dilakukan secara pasif (passive case finding) yaitu penjaringan suspek TB paru dilaksanakan hanya pada penderita yang berkunjung ke sarana pelayanan kesehatan terutama Puskesmas, sehingga penderita yang tidak datang masih menjadi sumber pernularan (Kementerian Kesehatan RI, 2012). Alternatif program pemberantasan TB paru adalah dengan Active Case Finding yaitu menjaring suspek TB paru dengan melibatkan peran serta masyarakat termasuk kader untuk meningkatkan angka cakupan (coverage) penemuan, pemeriksaan dan pengobatan TB paru. Menurut Depkes (2002) kader merupakan kunci keberhasilan program peningkatan pengetahuan dan ketrampilan bidang kesehatan dalam masyarakat. Penemuan penderita TB paru secara aktif di masyarakat sangat penting untuk mencegah penularan lebih lanjut (Wahyudi, 2010). Keberadaan kader di masyarakat dalam pengendalian kasus TB sangat strategis karena kader dapat berperan sebagai penyuluh, membantu menemukan tersangka secara dini, merujuk penderita dan sekaligus menjadi PMO bagi penderita TB secara langsung (Boy, 2015).

Kasus TB paru yang tidak segera ditemukan dan diobati menyebabkan terjadinya transmisi dan bisa menyebabkan TB RO (Resistensi Obat). Rendahnya angka penemuan kasus TB paru disebabkan oleh beberapa faktor antara lain sistem surveilance yang belum kuat, kemampuan mendiagnosis penyakit TB paru yang masih kurang dan kurangnya akses masyarakat ke pelayanan kesehatan. Beberapa studi menyatakan masyarakat masih mempunyai pengetahuan yang kurang tentang penyakit TB paru dan sistem penjaringan penderita melalui anamnese yang belum optimal, hal ini mempengaruhi rendahnya cakupan suspek yang diperiksa.

Upaya untuk menemukan kasus TB di masyarakat dalam rangka meningkatkan 
kesehatan masyarakat termasuk salah satu peran kader yang perlu diperkuat, salah satunya melalui edukasi kepada kader. Model deteksi dini TB oleh kader ini konsisten dangan salah satu elemen dalam Stop TB Partnership untuk menghentikan TB yaitu pemberdayaan pasien dan komunitas sehingga dapat mengurangi ketergantungan masyarakat kepada petugas kesehatan untuk memecahkan masalah kesehatan mereka (Sumartini, 2014). Beberapa studi menunjukkan bahwa pengetahuan, sikap, motivasi, pelatihan, dukungan pemegang program merupakan variabel yang berpengaruh pada perilaku kader dalam penemuan penderita TB paru (Fadhilah et al., 2014; Wahyudi, 2010; Pebryanty et al., 2017). Pengetahuan merupakan komponen penting dan berpengaruh langsung pada kinerja seseorang. Pengetahuan di perlukan untuk membantu tindakan yang menghasilkan kinerja. Sosialisasi dalam bentuk pelatihan dan pendampingan mampu memberikan daya ungkit terhadap penemuan kasus TB paru. Hasil penelitian menunjukkan kader yang mempunyai pengetahuan baik akan lebih baik dalam penemuan kasus TB paru (Nisa et., 2017). Informasi yang diperoleh melalui pelatihan berdampak pada meningkatnya pengetahuan kader tentang penanggulangan TB paru. Adapun hasil yang didapat kader saat pelatihan antara lain menambah pengetahuan tentang penyakit TB paru, mengenali gejala penyakit TB sejak dini, memahami pentingnya penemuan kasus TB, pengobatan dan juga pencegahan TB paru. Dalam pelatihan kader juga diajarkan cara berkomunikasi yang baik dengan masyarakat. Pelatihan yang diikuti kader di Muhammadiyah dan Aisyiyah menunjukkan setelah mereka mengikuti pelatihan mereka terampil, tanggap dan cekatan dalam menentukan tindakan yang diambil saat menjumpai masyarakat menderita suspek TB paru (Fadhilah et al., 2014).

Penyakit TB paru menjadi salah satu fokus perhatian pemerintah Provinsi Jawa Tengah. Angka penemuan kasus (Case Detection Rate/CDR) merupakan indikator dalam pencapaian MDG's. Case Detection Rate menggambarkan cakupan penemuan pasien baru BTA positif pada wilayah tersebut. Target CDR program penanggulangan TB nasional minimal 70\%. Kondisi saat ini CDR secara nasional di Indonesia masih dibawah target yaitu 42,4\%. Angka Kematian TB di Kabupaten Banyumas selama lima tahun terus mengalami peningkatan, dari 1,6 per 100.000 penduduk pada tahun 2014 menjadi 3,1 per 100.000 penduduk di akhir tahun 2017(Astuti et al., 2018). Insiden TB paru di Kabupaten Banyumas tahun 2017 sebesar 174,88 per 100.000 penduduk dan angka penemuan kasus TB BTA positif (CDR) tahun 2017 sebesar 70,01, hal ini menunjukkan Kabupaten Banyumas termasuk kategori risiko sedang dalam kasus TB paru. Kegiatan penanggulangan TB paru untuk daerah kategori risiko sedang antara lain penemuan pasien secara aktif, peningkatan kapasitas PMO dan pelacakan kasus, melakukan surveilans aktif dan peningkatan penemuan TB paru melalui kolaborasi layanan. Walaupun secara cakupan kabupaten CDR termasuk kategori beresiko sedang, tetapi masih ada beberapa Puskesmas dengan cakupan CDR rendah. Berikut ini 5 Puskesmas dengan nilai CDR terendah (kurang dari 20\%) pada tahun 2017 yaitu Puskesmas Purwokerto Utara I, Purwokerto Timur II, Kembaran I, Sokaraja I, dan Purwokerto Barat. Salah satu desa di wilayah kerja Puskesmas Kembaran I yang nilai CDR nya terendah adalah Desa Linggasari. Desa Linggasari merupakan desa salah satu desa dengan tingkat sosial ekonomi rendah. Kader yang ada di Linggasari mempunyai pengetahuan yang terbatas tentang TB paru, yang berdampak pada sedikitnya penemuan aktif penderita TB paru di Desa Linggasari. Penemuan penderita merupakan ujung tombak keberhasilan pengobatan dan pencegahan transmisi penyakit TB paru. Desa 
Linggasari juga merupakan desa binaan Fakultas Ilmu ilmu Kesehatan Unsoed. Desa ini terdiri dari 4 dusun, 4 RW dan 24 RT. Masing-masing dusun terdiri dari 2 RW dan 6 RT. Desa ini merupakan desa terluas di wilayah kerja Puskemas Kembaran I yaitu 390 Ha. Sebagian besar penduduknya sebagai petani dan buruh. Jenis layanan kesehatan yang ada di desa yaitu 1 PKD (Pos Kesehatan Desa) dan 9 Posyandu.

\section{METODE PELAKSANAAN}

Metode yang digunakan dalam kegiatan pengabdian kepada masyarakat ini adalah pengkaderan, pendidikan \& pelatihan dan pendampingan dengan sasaran kader Desa Linggasari Kecamatan Kembaran Kabupaten Banyumas. Kegiatan pengabdian masyarakat ini melibatkan perangkat Desa, kader kesehatan, dinas kesehatan, dosen dan mahasiswa Jurusan Kesehatan Masyarakat Fakultas Ilmu Ilmu Kesehatan Universitas Jenderal Soedirman. Berikut ini solusi yang dilakukan untuk membantu menyelesaikan permasalahan: 1) Pembentukan tim kader desa TOSS TB 2) Pendidikan \& pelatihan untuk kader 3)Pendampingan.

\section{HASIL DAN PEMBAHASAN}

Kegiatan ini dilaksanakan pada bulan Mei - Oktober 2019. Kegiatan pengabdian ini terdiri dari persiapan, pelaksanaan, monitoring dan evaluasi. Persiapan dalam kegiatan meliputi diskusi dengan perangkat desa, kader dan dinas kesehatan mengenai permasalahan mitra dan upaya-paya pemecahannya. Dari diskusi ini disepakati terkait dengan rencana pelaksanaan kegiatan. Pada tahap persiapan juga dipersiapan sarana prasarana dalam pendidikan dan pelatihan yaitu buku panduan penemuan penderita tuberkulosis paru untuk kader. Berikut ini penjelasan setiap kegiatan yang dilakukan untuk menyelesaikan permasalahan pada mitra:

a) Pengkaderan Temukan Obati Sampai Sembuh (TOSS) TB paru

Kegiatan pengkaderan TOSS TB paru ini mempunyai tujuan untuk membentuk tim kader desa TOSS TB Paru. Kader ini yang bertugas untuk menemukan penderita, menyarankan untuk segera periksa dan mendampingi dalam pengobatan. Kegiatan pengkaderan dilaksanakan pada tanggal 15 Juli 2019 bertempat di Balai Desa Linggasari dengan mengundang kader, perangkat desa, dan dari Dinas Kesehatan Kabupaten Banyumas. Dinas Kesehatan yang hadir pada saat pembentukan tim kader yaitu Bu Misti SKM, selaku memegang program TB paru di Dinkes Banyumas. Perangkat desa yang hadir untuk menyaksikan pelantikan yaitu sekretaris desa dan beberapa perangkat Desa Linggasari Linggasari. Kegiatan ini menunjukkan proses pengkaderan sudah berjalan dan sudah dibentuk tim kader desa TOSS TB, dari belum ada sekarang sudah ada tim kadernya. Adapun susunan pengurus kader desa TOSS TB di Desa Linggasari terdiri dari pengarah Sekdes Linggasari (Suparno), ketua Rohyati, wakil ketua Kusyati, sekretaris Maulida, bendahara Karsini, anggota berjumlah 15 orang. Masing masing pengurus dan anggota kader TOSS TB bertanggungjawab untuk melakukan penemuan dan pendampingan penderita TB yang berada di wilayah lokasi RT masing-masing. Ketua dan pengurus akan merekap data penderita yang dilaporkan masing-masing kader di masingmasing RT, kemudian akan melaporkan ke bidan desa atau Puskesmas Kembaran. Jika ada hal yang penting untuk diskusi, maka pengurus dan kader akan berkoordinasi dengan Puskesmas Kembaran dan Dinas Kesehatan Kabupaten Banyumas.

Rejeki et al. 2019. Pemberdayaan Kader Pendeteksi Tuberkulosis Paru | 


\section{b) Pendidikan dan Pelatihan}

Pada kegiatan pendidikan ini mencakup juga persiapan, pelaksanaan dan evaluasi. Pada tahap persiapan meliputi koordinasi dengan dinas kesehatan, pamong desa terkait teknis pelaksanaan, yang menyangkut waktu, tempat, undangan dan sarana pendukung. Persiapan bahan meliputi persiapan materi yang terdiri dari bahan presentasi dan buku modul. Materi pelatihan meliputi informasi tentang kebijakan program penanggulangan TB paru, informasi dasar tentang TB paru, pemberdayaan kader untuk penanggulangan TB paru dan penemuan kasus TB baru oleh kader. Ada dua narasumber dalam kegiatan ini yaitu dari Unsoed dan dinas kesehatan Kabupaten Banyumas. Untuk mendukung materi pelatihan menjadi lebih lengkap maka dibuat modul. Buku modul pelatihan terdiri dari 2 bab yaitu bab informasi dasar TB Paru dan strategi penemuan kasus TB Paru. Pada bab informasi dasar TB Paru berisi materi antara lain: deskripsi singkat, gejala TB paru, cara penularan, jenis pemeriksaan TB, pengelompokkan pasien TB, penyakit Komorbid TB, tata laksana pasien TB, pencegahan penularan. Pada bab strategi penemuan kasus TB Paru berisi informasi tentang: pengertian strategi penemuan kasus, macam strategi penemuan kasus, penemuan aktif, investigasi kontak, pemetaan kasus, pelaksaan investigasi kontak dan komunikasi dan edukasi. Kegiatan pendidikan dan pelatihan telah dilaksanakan pada tanggal 15 Juli 2019 bertempat di Desa Linggasari dengan dihadiri 20 kader Desa Linggasari, dari 20 undangan yang disebar. Hal ini menunjukkan antusias kader untuk hadir dalam kegiatan tersebut. Berikut ini karakteristik peserta pelatihan: rata-rata umur kader adalah 40 tahun, berpendidikan SLTP-SLTA dan merupakan kader posyandu di masing-masing dusun. Kegiatan ini berjalan dengan lancar, semua peserta antusias aktif dalam kegiatan pelatihan, hal ini terbukti dengan banyaknya sesi diskusi dan tanya jawab antara peserta dan narasumber. Untuk mengevaluasi keberhasilan pendidikan dan pelatihan dilakukan pre test dan post tes pada kader. Hasil pengolahan data menunjukkan rata-rata skor pengetahuan pada pre test adalah 13,05 dengan standar deviasi 0,97 . Pada post test, didapat rata-rata skor pengetahuan adalah 14,16 dengan standar deviasi 0,76 . Hal ini menunjukkan terjadinya peningkatan skor pengetahuan sebelum dan sesudah kegiatan pendidikan/pelatihan. Hasil uji statistik didapatkan nilai $\mathrm{p}=0,001$, artinya ada perbedaan yang signifikan antara skor pengetahuan sebelum dan sesudah pendidikan/pelatihan. Adapun beberapa pernyataan yang dijawab salah oleh kader pada saat pre test antara lain tentang TB pada anak dan upaya pencegahan TB paru. Jumlah item soal yang dijawab benar oleh responden pada saat kondisi awal sejumlah $68,7 \%$ naik menjadi $75,51 \%$ pada kondisi akhir kegiatan. Hal ini menunjukkan kegiatan pendidikan dan pelatihan pada kader berhasil meningkatkan pengetahuan kader. Hasil studi di Tegal dari analisis suatu pelatihan kepada kader posyandu juga menunjukkan hasil sama yaitu terdapat perbedaan tingkat pengetahuan dan ketrampilan kader dalam pengukuran antropometri sebelum dan sesudah pelatihan(Fitri \& Mardiana, 2011). Hasil kajian di Surakarta tentang pendidikan dan pelatihan pada kader dengan menggunakan buku modul panduan didapatkan hasil terjadinya peningkatan pengetahuan sebelum dan sesudah kegiatan. Dengan adanya buku modul, memudahkan kader untuk mengakses informasi mengenai materi yang disampaikan(Untari, Prananingrum, Pertiwi, \& Kusumadaryati, 2017). Pendidikan dan pelatihan dengan menggunakan alat bantu buku modul ini juga efektif sehingga berhasil meningkatkan pengetahuan dan ketrampilan petugas kesehatan(Rejeki, Kuswanto, \& Nurlaela, 2014). 


\section{c) Pendampingan}

Selama periode pengabdian yaitu kurang lebih 3 bulan, tim pengabdian masyarakat dari Unsoed akan melakukan pendampingan dan bimbingan kepada kader dalam penemuan kasus TB paru. Dalam pendampingan tim pengabdian Unsoed juga bekerjasama dengan dinas kesehatan dan juga Puskesmas mengenai kegiatan penemuan dan pelaporan kasus TB paru ini. Tim dari Unsoed ke Desa Linggasari untuk melakukan pendampingan sebanyak 4 kali. Pada kunjungan pertama terdapat beberapa pertanyaan yang disampaikan kader antara lain : adanya penderita yang malas untuk berobat, berhenti minum obat, dan perilaku yang kurang baik oleh penderita (misal batuk dan buang dahak), maka tim dari Unsoed akan memberikan informasi yang benar. Pada kunjungan pendampingan kedua ditemukan kader yang mengajukan keluhan adanya pasien yang susah diingatkan dalam pengobatan, pasien tersebut drop out pengobatan. Tim Unsoed melakukan pendampingan dengan bersama kader mendatangi pasien tersebut dan memotivasi agar kembali periksa dan melakukan pengobatan sampai tuntas. Pada kunjungan pendampingan ketiga tim Unsoed berkoordinasi dengan kader agar bisa berkomunikasi dengan baik dengan pasien, keluarga dan masyarakat. Tim menyampaikan bagaimana cara komunikasi yang efektif dan persuasif untuk mengajak masyarakat yang mempunyai gejala penyakit Tuberkulosis Paru untuk segera berobat ke pelayanan kesehatan. Pada pendampingan keempat tim Unsoed mendengarkan cerita dan pengalaman dari kader saat menjalankan tugasnya menemukan dan mendampingi penderita TB paru. Para kader menyampaikan satu per satu pengalamannya dalam pendampingan kemudian dibahas bersama antara tim Unsoed, dinas kesehatan/Puskesmas dan kader. Hasil pendampingan menunjukkan semakin baiknya tingkat pengetahuan dan pemaham kader TOSS TB mengenai penyakit TB paru, pentingnya penemuan dan pengobatan penderita sampai tuntas. Hasil kajian ini serupa dengan hasil kajian di Sleman, yaitu adanya pendampingan kader peningkatan pengetahuan dan ketrampilan kader mengenai cara memproduksi MP-ASI yang sehat(Purwati, Salmiyati, \& Imallah, 2018).

\section{KESIMPULAN}

Kegiatan pemberdayaan kader pendeteksi Tuberkulosis paru di Desa Linggasari Kecamatan Kembaran Kabupaten Banyumas sudah dilaksanakan dengan baik, dan hasilnya kader sudah berperan dalam mendeteksi penderita Tuberkulosis dan melakukan pendampingan dalam pemeriksaan maupun pengobatan. Dengan penemuan penderita TB Paru cepat maka dapat segera dilakukan pengobatan sampai tuntas sehingga masyarakat Desa Linggasari menjadi sehat dan produktif.

\section{UCAPAN TERIMAKASIH}

Ucapan terimakasih penulis sampaikan kepada Universitas Jenderal Soedirman, atas pendanaan pengabdian masyarakat ini. 


\section{DAFTAR PUSTAKA}

Astuti, S. D., Wijayanti, S. P. M., Devi Octaviana. 2018. Gambaran Sistem Surveilans Tuberkulosis dalam mendukung Upaya Pengendalian TB-RO. Jurnal Kesehatan Masyarakat Nasional, 10(2), 124-133.

Boy, E. 2015. Efektifitas Pelatihan Kader Kesehatan dalam Penangan Tuberkulosis di Wilayah Binaan. Jurnal Pendidikan Kedokteran Indonesia, 4(2), 83-89.

Fadhilah. 2014. Perilaku Kader dalam Penemuan Suspek Tuberkulosis. Kesmas, 8(6), $280-283$.

Fitri, H., Mardiana. 2011. Pelatihan terhadap Ketrampilan Kader Posyandu. Jurnal Kesehatan Masyarakat, 7(1), 22-27.

Kementerian Kesehatan RI. 2012. Pedoman Pencegahan dan Pengendalian Penyakit Infeksi Tuberkulosis di Fasilitas Pelayanan Kesehatan.

Kementerian Kesehatan RI. 2018. Tuberkulosis. Pusat Data dan Informasi Kesehatan.

Kemenkes Republik Indonesia. 2019. Situasi TBC Indonesia. Jakarta. Retrieved from https://www.tbindonesia.or.id/page/view/11/situasi-tbc-di-indonesia

Nisa, S. M., Yunita Dyah P.S. 2017. Hubungan antara karakteristik kader kesehatan dengan praktik penemuan tersangka kasus Tuberkulosis Paru. Journal of Health Education, 2(1), 93-100.

Pebryanty, P., Restuastuti, T., Zahtamal. 2017. Pengetahuan dan Tindakan Kader TB dalam Upaya Pengendalian Penyakit TB Paru di Kabupaten Meranti. JOM FK, $4(2), 1-14$.

Purwati, Y., Salmiyati, S., Imallah, R. N. 2018. Pendampingan Kader Kesehatan dalam Strategi Produksi dan Promosi MP-ASI. Abdimas Dewantara, 1(2), 96-108.

Rejeki, D. S. S., Kuswanto, Nurlaela, S. 2014. Pelatihan pengolahan Data Epidemiologi Bagi Petugas Surveilans Penyakit Menular di Kabupaten Banyumas. Jurnal Kesmas Indonesia, 6(3), 223-232.

Reyn, C. F. Von. 2013. Tuberculosis. The New England Journal of Medicine, 368(8), 745-755. http://doi.org/10.1056/NEJMra1200894

Sumartini, N. P. 2014. Penguatan peran kader kesehatan dalam penemuan kasus tuberkulosis (TB) BTA positif melalui edukasi dengan pendekatan Theory of Planned Behaviour. Jurnal Kesehatan Prima, 8(1), 1246-1263.

Wahyudi, E. 2010. Hubungan Pengetahuan, Sikap dan Motivasi Kader dengan Penemuan Suspek Tuberkulosis Paru di Puskesmas Sanankulon. Universitas Sebelas Maret Surakarta.

Untari, I., Prananingrum, R., Pertiwi, D., Kusumadaryati, D. 2017. Peningkatan Pengetahuan dan Ketrampilan Kader Dalam Pelayanan Posyandu Balita Melalui Pelatihan Dengan Metode Student Center Learning. Jurnal Universitas Muhammadiyah Magelang, 1, 15-18. 